\title{
Inhibitory effects of Schisandrin B on human prostate cancer cells
}

\author{
MOUSSA IDE NASSER, TINGYU HAN, SALAH ADLAT, YUXIN TIAN and NAN JIANG \\ Colleges of Life Science and Technology, Dalian University, \\ Dalian Economical Technological Development Zone, Liaoning 116622, P.R. China
}

Received January 9, 2018; Accepted July 25, 2018

DOI: $10.3892 / o r .2018 .6791$

\begin{abstract}
Prostate cancer is a serious affliction worldwide. Although much progress has been made in the study of prostate cancer prevention and treatment, less attention has been paid to the molecular mechanism of the disease. The molecular arrangement by which Schisandrin B (Sch B) induces human prostate cancer cytotoxicity was comprehensively examined in the present study. As indicated by the results of flow cytometric and western blot analysis, Sch B could inhibit prostate cancer cell proliferation and promote DU145 and LNCaP cell apoptosis and S-phase cell arrest. Moreover, real-time PCR, flow cytometry and western blot result revealed that the cell apoptosis process induced by Sch B in LNCaP cells was associated with its capacity to generate oxidative stress, its inhibition of androgen receptor and the phosphorylation of PI3K/AKT and STA3/JAK2. The data from the present study demonstrated the antitumor effects and the potential pharmacological application of Sch B as an efficient drug for prostate cancer.
\end{abstract}

\section{Introduction}

As a common cancer of men, prostate cancer (PC) gradually becomes an androgen-independent phenotype following its dependence on androgens for proliferation. PC is resistant to chemotherapy and secondary endocrine therapy in the androgen-independent phenotype $(1,2)$. PC is accompanied by various molecular changes, particularly the elevation of serum interleukin-6 (IL-6) (3).

IL-6 is a multifunctional cytokine and is related to the differentiation and growth of all types of malignant tumors including prostate carcinomas (4). IL- 6 has been demonstrated to be associated with the transformation of PC to an androgen-independent state from an androgen-dependent state. IL-6 uses many cellular transducers and mediators through the receptor, such as phospho-Akt (S473), phosphorylated ERK1/2 (T202/Y204) and Janus kinase (JAK)/signal transducer and

Correspondence to: Dr Nan Jiang, Colleges of Life Science and Technology, Dalian University, Dalian Economical Technological Development Zone, 10 Xuefu Avenue, Liaoning 116622, P.R. China E-mail: jiangnan678@sohu.com

Key words: prostate, AR, PI3K/AKT, STAT3/JAK2 activator of transcription (STAT). p-STAT3 is the key component of the JAK/STAT pathway. Consequently, the JAK/STAT pathway is regarded as a target of novel therapies $(5,6)$.

Recent research results have indicated that androgen receptor (AR) transactivation can be activated through IL-6 in human prostate cancer (LNCaP) cells in an androgen-independent manner. Although the PI3K pathway is considered to be the main contributor to IL-6 signaling, its role in activation of AR by IL- 6 is debated. PI3K can activate AR through IL-6. However, activation of AR-mediated by IL-6 does not depend on the PI3K pathway $(7,8)$.

Sch B, extracted from the fruit of Schisandra chinensis, has been applied to treat diseases, including myocardial disorders and hepatitis $(9,10)$. Sch B has antitumor activities in various types of cancers including cholangiocarcinoma, gastric, breast and glioma (11-13). Recent studies have demonstrated that, due to its low substantial antioxidant and anti-inflammatory activity, Sch B may attenuate metastasis invasion in cancer $(14,15)$.

However, to the best of our knowledge, the influences of Sch B on prostate cancer cells and the corresponding mechanism have not been previously reported. The present study investigated the anticancer effect of Sch B on prostate cell lines and its molecular mechanism, and demonstrated that Sch B can be used as a novel and natural anti-prostate cancer drug.

\section{Materials and methods}

Chemicals and reagents. Sch B was purchased from Baoji Herbest Bio-tech Co., Ltd.,(Beijing, China). Fetal bovine serum (FBS) was purchased from Hangzhou Sijiqing Biological Engineering Material, Co., Ltd. (Beijing, China). Dulbecco's modified Eagle's medium (DMEM) was obtained from Gibco (Thermo Fisher Scientific, Inc., Waltham, MA, USA). 3-4-5-Dimethylthiazol-2-yl-25-diphenyltetrazolium bromide (MTT) and dimethyl sulfoxide (DMSO) were purchased from Sigma-Aldrich (Darmstadt, Germany). An apoptosis kit, a Cell Cycle kit, a Reactive Oxygen Species (ROS) kit, and Rhodamine 123 and DAPI staining kits as well as RIPA were purchased from Beyotime Institute of Biotechnology (Beijing, China). Antibodies against phospho-PI3 kinase (1:1,000; cat. no. 4249), phospho-anti-Akt antibody (1:1,000; cat. no. 9272), JAK2 (1:1,000, cat. no. 3230), p-Jak2 (1:1,000; cat. no. 3771), p-ERK (1:2,000; cat. no. 4370), p38 (1:500; cat. no. 8690$)$, STAT3 (1:1,000; cat. no. 12640), p-STAT3 
(1:500; cat. no. 9145), Bcl-2 (1:1,000; cat. no. 2872) and Bax (1:1,000; cat. no. 2774) antibodies were purchased from Cell Signaling Technology, Inc. (Danvers, MA, USA). Cyclin D1 (1:500; cat. no. Sc-8396), cyclin A (1:1,000; cat. no. 271682), cyclin E (1:1,000; cat. no. Sc-48420), CDK2 (1:500; cat. no. Sc-70829), mouse (1:500; cat. no. Sc-2791), anti-rabbit (1:1,000; cat. no. Sc-2774) and p53 (1:1,000; cat. no. Sc-47698), antibodies were purchased from Santa Cruz Biotechnology, Inc. (Dallas, TX, USA).

Ethics. All ethical and laboratory guidelines were followed and no misidentified cell lines were used. The LNCaP, DU145, SGC-7901 and SW480 cell lines were purchased from the American Type Culture Collection (ATCC; Manassas, VA, USA).

Cell culture. The LNCaP, DU145, SGC-7901 and SW480 cell lines were cultured and maintained in DMEM containing $10 \%$ FBS. Cells were incubated at $37^{\circ} \mathrm{C}$ in a humidified atmosphere with $5 \% \mathrm{CO}_{2}$ and allowed to grow to $70-80 \%$ confluence.

Cell proliferation assay. Cells were cultured and maintained in DMEM, containing $1 \% \mathrm{FBS}$ then incubated at $37^{\circ} \mathrm{C}$ in a humidified atmosphere of $5 \% \mathrm{CO}_{2}$ and allowed to grow to $70-80 \%$ confluence. Then, the cells were harvested and seeded in a 96-well plate to a final concentration of $5 \times 10^{3}$ cells/well and incubated in DMEM containing $1 \%$ FBS for $24 \mathrm{~h}$. Next, the cells were treated with $0,50,100,150$ and $200 \mu \mathrm{M}$ of Sch B, and incubated for 24,48 or $72 \mathrm{~h}$. Subsequently, $20 \mu \mathrm{l}$ of MTT solution $(5 \mathrm{mg} / \mathrm{ml})$ was added to each well and then incubated for $4 \mathrm{~h}$. Finally, the medium was discarded and $150 \mu \mathrm{l}$ of DMSO was added to each well. The plates were read at a wavelength of $570 \mathrm{~nm}$ using Varioskan Flash Multimode Reader (Thermo Fisher Scientific, Inc.). A total of 6 reduplicate wells were used for each treatment, and experiments were repeated 3 times. Their inhibition ratio (I \%) was based on the equation (18).

$$
\mathrm{I} \%=[\text { A570 (control) }- \text { A570 (treated) }] / \text { A570 (control) } \times 100
$$

Where, $\mathrm{I}$ is the inhibition rate and $\mathrm{A}$ is the absorbance at $570 \mathrm{~nm}$.

Annexin V/PI assay for apoptosis. Apoptotic cells were investigated by Annexin V/PI staining followed by flow cytometry according to the manufacturer's protocol. LNCaP and DU145 cells $\left(5 \times 10^{3}\right.$ cells/well) were cultured in 6-wells plates and treated with different concentrations $(12.5,25$ and $50 \mu \mathrm{M})$ of Sch B for $48 \mathrm{~h}$. Then, the cells were washed twice with PBS and then stained with $5 \mu \mathrm{l}$ of Annexin V-FITC and $10 \mu \mathrm{l}$ of PI in $500 \mu \mathrm{l}$ binding buffer for $15 \mathrm{~min}$ at room temperature in the dark. The apoptotic cells were determined by flow cytometry (Cytomics FC 500; Beckman Coulter Inc., Miami, FL, USA).

Determination of LNCAP cell cycle distribution. The cell cycle distribution in different phases following exposure to Sch B was analyzed by flow cytometry. In brief, LNCaP cells $\left(5 \times 10^{3}\right.$ cells/well plates) were seeded into 6 -well plates, and exposed to different concentrations $(12.5,25$ and $50 \mu \mathrm{M})$ of Sch B for 48 h. The cells were harvested, washed with PBS twice and subsequently fixed with $70 \%$ ethanol for $2 \mathrm{~h}$. The cells were centrifuged at $67 \mathrm{x}$ g for 4 min and washed with PBS, resuspended in $500 \mu \mathrm{l}$ of buffer containing $10 \mu \mathrm{l}$ of RNase and $25 \mu \mathrm{l}$ of PI, and incubated at room temperature in the dark for $15 \mathrm{~min}$. The distributions of the cell cycle were determined by flow cytometry (Cytomics FC 500; Beckman Coulter Inc.).

Detection of ROS. The generation of ROS was determined with 2,7-dichlorofluorescein diacetate (DCFH-DA) according to the manufacturer's instructions. In brief, $\mathrm{LNCaP}$ cells were cultured $\left(5 \times 10^{3}\right.$ cells/well), incubated with or without NAC for $1 \mathrm{~h}$ and then treated with Sch B $(0,12.5,25$ and $50 \mu \mathrm{M})$ for $48 \mathrm{~h}$. The cells were collected, centrifuged at $67 \mathrm{x} \mathrm{g}$ for $4 \mathrm{~min}$ and washed with PBS, then resuspended in PBS containing $10 \mu \mathrm{M}$ of DCFH-DA and incubated at room temperature in the dark for $15 \mathrm{~min}$. The cells were then washed with PBS and measured immediately using a flow cytometer (Cytomics FC 500; Beckman Coulter Inc.) to monitor the formation of the fluorescent-oxidized derivative of DCFH-DA at an emission wavelength of $525 \mathrm{~nm}$ and an excitation wavelength of $488 \mathrm{~nm}$.

Flow cytometry of Rhodamine 123. The changes induced by Sch B in the mitochondrial membrane were determined by Rhodamine 123 staining according to the manufacturer's instructions. Briefly, LNCaP cells $\left(5 \times 10^{3}\right.$ cells/well) were seeded in 6-well plates and then treated with or without NAC and incubated at $37^{\circ} \mathrm{C}$ for $1 \mathrm{~h}$. Subsequently, the cells were treated with or without $12.5,25$ or $50 \mu \mathrm{M}$ Sch B for $48 \mathrm{~h}$ and stained with Rhodamine 123 for $15 \mathrm{~min}$ at $37^{\circ} \mathrm{C}$. Mitochondrial membrane potential (MMP) was detected by flow cytometry (Cytomics FC 500; Beckman Coulter Inc.).

Western blot analysis. The protein expression regulated by Sch B was analyzed by western blotting and followed the protocol as previously described (16) with small modifications. In brief, LNCaP and DU145 cells were treated with 12.5, 25 or $50 \mu \mathrm{M}$ of Sch B for $48 \mathrm{~h}$ and then harvested and lysed with RIPA buffer. Subsequently, the insoluble protein lysate was removed by centrifugation at $12,225 \mathrm{x}$ for $15 \mathrm{~min}$ at $4^{\circ} \mathrm{C}$. The protein concentrations were determined using a NanoDrop 1000 spectrophotometer (Thermo Fisher Scientific, Inc., Wilmington, DE, USA). An equal amount of protein was loaded on SDS-PAGE electrophoresis gel (10 or $12 \%$ according to the protein size) and the gel was transferred onto polyvinylidene fluoride (PVDF) membranes. The membranes were blocked in $5 \%(\mathrm{w} / \mathrm{v})$ non-fat milk and incubated for $2 \mathrm{~h}$. The membranes were thereafter incubated with appropriate primary antibodies at $4^{\circ} \mathrm{C}$ overnight and washed three times with a Tris-buffered saline-Tween solution (TBST). Finally, the blots were incubated with appropriate secondary antibodies (anti-rabbit or anti-mouse horseradish peroxidase-conjugated) for $1 \mathrm{~h}$ at room temperature, then washed with TBST for $30 \mathrm{~min}$. Signals were detected using ECL plus chemiluminescence kit on X-ray film (EMD Millipore, Billerica, MA, USA).

Reverse transcription-quantitative polymerase chain reaction (RT-qPCR). Total RNA was extracted using TRIzol (Life Technologies; Thermo Fisher Scientific, Inc.), according to the manufacturer's protocols. Briefly, first-stand cDNA was reverse-transcribed from $1 \mu \mathrm{g}$ total RNA using the Super-Script 
First-Strand cDNA System (Invitrogen; Thermo Fisher Scientific, Inc.) and amplified by Platinum SYBR-Green qPCR Super Mix-UDG (Invitrogen; Thermo Fisher Scientific, Inc.). A Master Mix was prepared for each PCR reaction, which included Platinum SYBR Green qPCR Super Mix-UDG, forward primer, reverse primer and $10 \mathrm{ng}$ of template cDNA. PCR conditions were $10 \mathrm{~min}$ at $95^{\circ} \mathrm{C}$, followed by 50 cycles at $95^{\circ} \mathrm{C}$ for $30 \mathrm{sec}$ and $60^{\circ} \mathrm{C}$ for $1 \mathrm{~min}$ and $72^{\circ} \mathrm{C}$ for $30 \mathrm{sec}$. The forward and reverse primer sequences were as follows: Akt forward, 5'-TCTATGGCGCTGAGATTGTG-3' and reverse, 5'-CTTAATGTGCCCGTCCTTGT-3'; and $\beta$-actin forward, 5'-CACGATGGAGGGGCCGGACTCATC-3 and reverse, 5'-TAAAGACCTCTATGCCAACACAGT-3'. Relative gene expression was obtained after normalization with $\beta$-actin and determination of the difference in cycle quantification $(\mathrm{Cq})$ between treated and untreated cells was performed using the $2^{-\Delta \Delta C q}$ method (17).

Transient transfection and luciferase assay. Luciferase assays were performed as previously described (18). Briefly, transient transfections were performed using Lipofectamine 2000 (Invitrogen; Thermo Fisher Scientific, Inc.) following the manufacturer's protocol. Cells were seeded into 48 -well plates for $16 \mathrm{~h}$ and transected with STAT3-Luc promoter $100 \mathrm{ng}$ in the presence of Renilla Luciferase control pREP7 vector $25 \mathrm{ng}$, and then treated with or without Sch B $(12.5,25$ and $50 \mu \mathrm{M})$. Firefly luciferase activities were calculated using the Dual-Luciferase reporter assay system (Promega Corp., Madison, WI, USA) and the ratio of firefly luciferase activity to Renilla luciferase activity was measured as the relative luciferase activity.

Statistical analysis. All statistical analyses were performed using Origin Lab software version 8.0 (Origin Lab, Northampton, MA, USA), and statistically significant differences between groups were determined by one-way ANOVA followed by Bonferroni post hoc test. $\mathrm{P}<0.05$ was considered to indicate a statistically significant difference.

\section{Results}

Cytotoxicity of Sch B in LNCaP cells. An MTT assay was used to determine the cell viability of human PC, gastric and colon cancer cells in presence of various concentrations of Sch B ranging 0-200 $\mu \mathrm{M}$ and incubated for 24,48 and $72 \mathrm{~h}$. As observed in Fig. 1 the results revealed a steady increase in growth inhibition in a concentration-dependent manner over the course of the incubation. Particularly, the estimated half-maximal inhibitory concentration $\left(\mathrm{IC}_{50}\right)$ value was 25,48 , 84 and $93 \mu \mathrm{M}$ for LNCaP, DU145, SW480 and SGC-7901 cells, respectively. Regarding these results it was evident that Sch B induced more cytotoxicity in PC cancer cells and particularly in the LNCaP cell line. We therefore performed the cytotoxicity of Sch B on LNCaP cells. The results revealed a steady increase in growth inhibition in a time dependent-manner respectively for 24,48 and $72 \mathrm{~h}$. The estimated half-maximal inhibitory concentration $\left(\mathrm{IC}_{50}\right)$ was 56,33 and $25 \mu \mathrm{M}$, respectively for 24,48 and $72 \mathrm{~h}$. In the present study, the concentrations of $12.5,25$ and $50 \mu \mathrm{M}$ were used for $48 \mathrm{~h}$ of incubation in subsequent experiments.

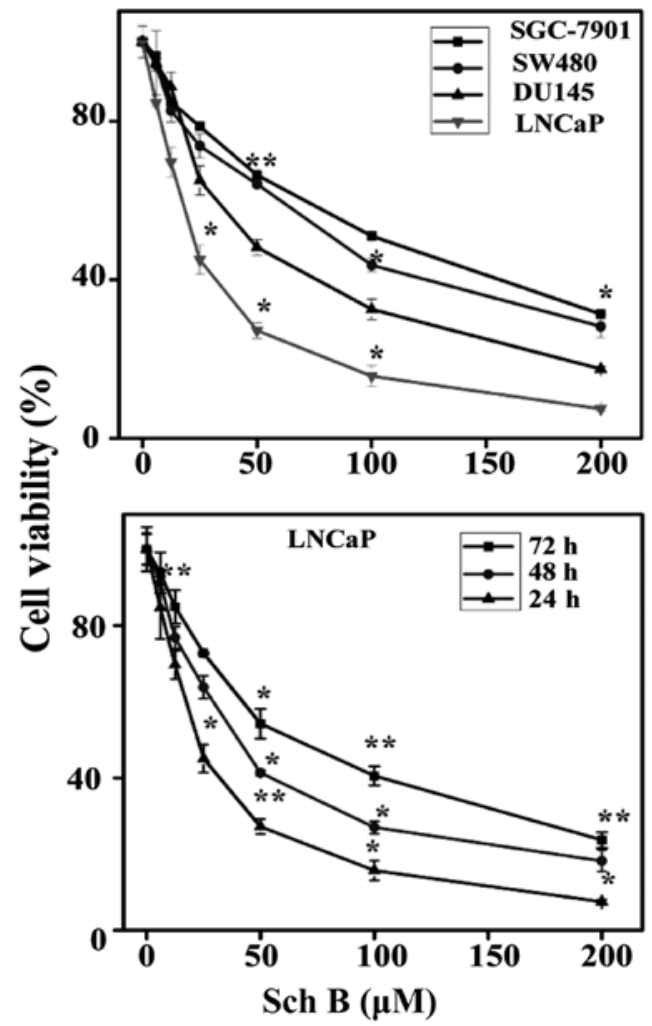

Figure 1. Cytotoxicity of Sch B on cancer cell lines. LNCaP, DU145, SGC-7901 and SW480 cell lines were treated with 0, 6, 12.5, 25, 50, 100, and $200 \mu \mathrm{M}$ of Sch B. Proliferation was assessed after $72 \mathrm{~h}$, as described in Materials and methods. ${ }^{*} \mathrm{P}<0.05$ and ${ }^{* *} \mathrm{P}<0.01$ compared with the control. (B) LNCaP cells were treated with $0,6,12.5,25,50,100$ and $200 \mu \mathrm{M}$ of Sch B for 24, 48 and $72 \mathrm{~h}$. Each bar represents the mean \pm standard deviation of three experiments. ${ }^{*} \mathrm{P}<0.05$ and ${ }^{* *} \mathrm{P}<0.01$ compared with the control. Sch $\mathrm{B}$, Schisandrin B.

Sch B induces apoptosis in LNCaP and DU145 cells. To determine whether the cell cytotoxicity induced by Sch B affected apoptosis, the cells were labeled with Annexin V and PI and then subjected to flow cytometry to determine the early apoptosis (B4), late apoptosis (B2) and necrosis (B1) of LNCaP and DU145 cells. As observed in Fig. 2A, Sch B induced apoptosis in both LNCaP and DU145 cells. The cell apoptosis rate of $\mathrm{B} 1+\mathrm{B} 2+\mathrm{B} 3$ was $27.19,49.09$ and $94.18 \%$ for the LNCaP cells after exposure to Sch B $(2.5,25$ and $50 \mu \mathrm{M}$ ) for $48 \mathrm{~h}$ and $17.73,37.45$ and $62.66 \%$ in theDU145 cells after respective exposure to Sch B $(2.5,25$ and $50 \mu \mathrm{M})$ for $48 \mathrm{~h}$. These data confirmed the results obtained from our MTT assay which revealed that following exposure to Sch B, LNCaP cells $\left(\mathrm{IC}_{50}=25\right)$ were more sensitive than DU145 cells $\left(\mathrm{IC}_{50}=48\right)$. Collectively, we therefore hypothesized that the cytotoxicity of Sch B was in time- and dose-dependent manner in PC cells.

To further assess the mechanism by which Sch B induced LNCaP and DU145 cell apoptosis, apoptosis-related proteins protein poly ADP-ribose (PARP), caspase-3 were analyzed. The results revealed that Sch B cleaved PARP and caspase-3 proteins expression (Fig. 2B).

Sch B generates ROS, and causes collapse in MMP. The generation of ROS serves a crucial role in the activation of mitochondrial-mediated apoptosis in PC (19). The present 
A
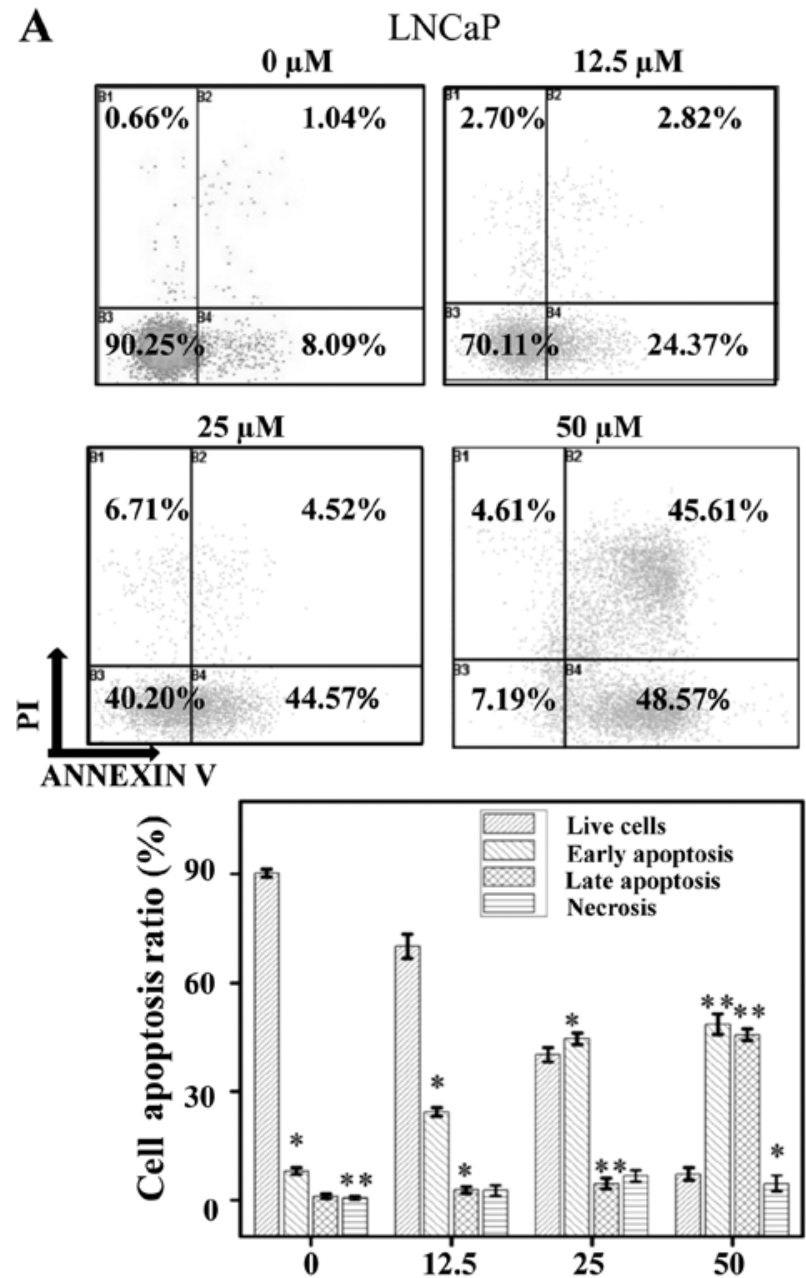

B
$\mathrm{LNCaP}$
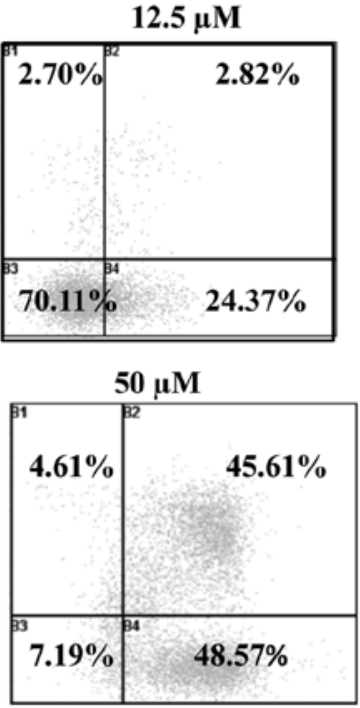

LNCaP
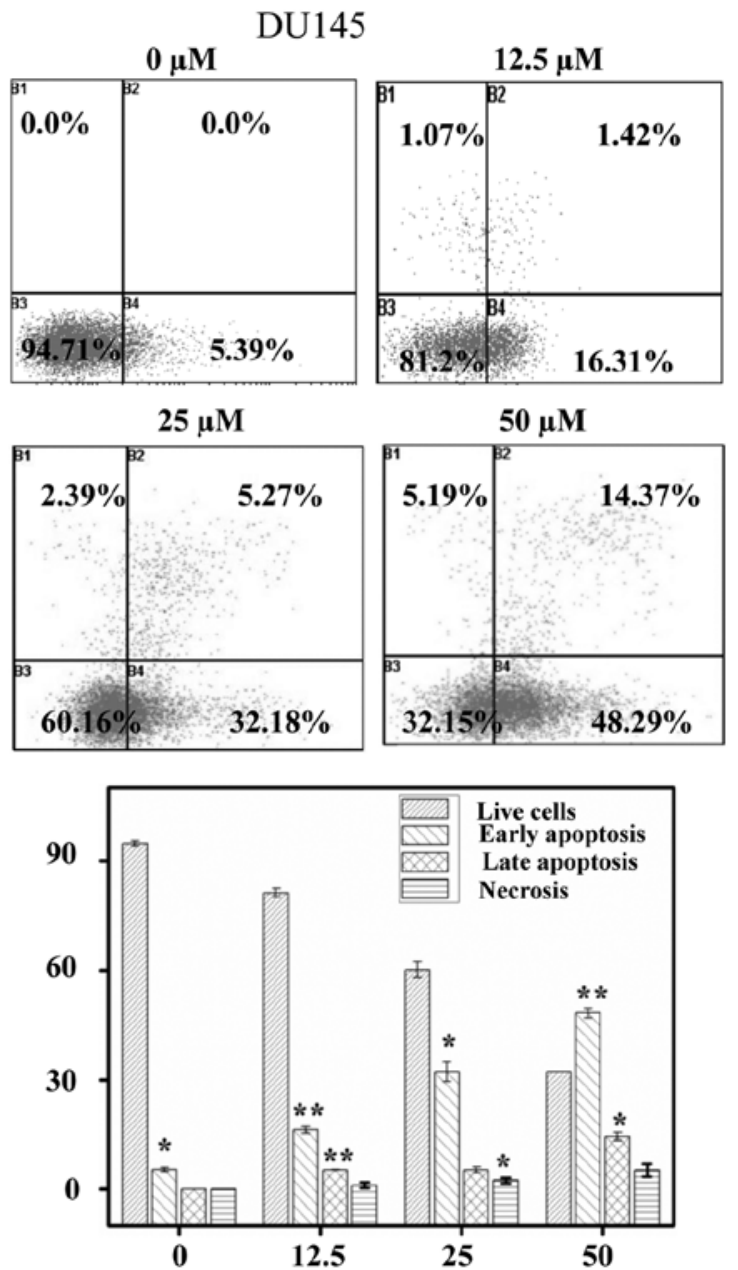

DU145

Concentration $(\mu \mathrm{M})$

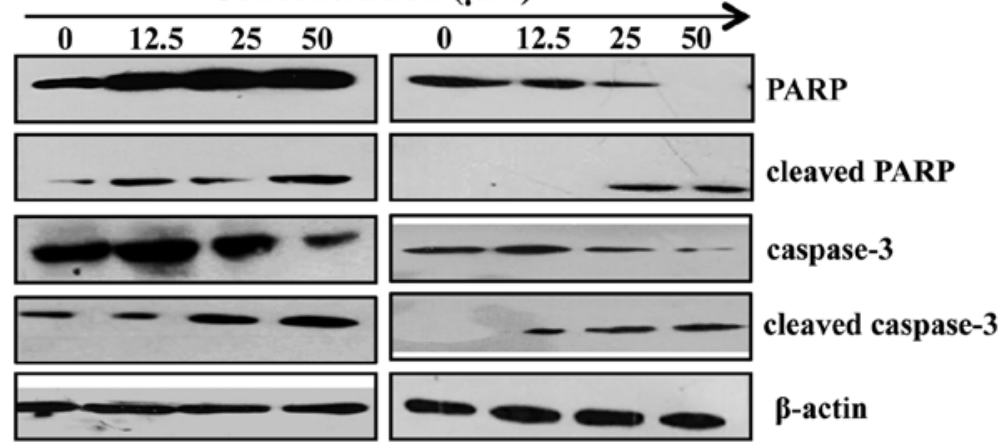

Figure 2. Mechanism of induction of apoptosis by Sch B on LNCaP and DU145 cells. (A) LNCaP cells were treated, with or without Sch B (0, $12.5,25$ and $50 \mu \mathrm{M}$ ). After $48 \mathrm{~h}$ the cells were stained with Annexin V/PI. The lower right quadrant exhibited Annexin $\mathrm{V}^{+} / \mathrm{PI}^{-}$, the upper right quadrant exhibited

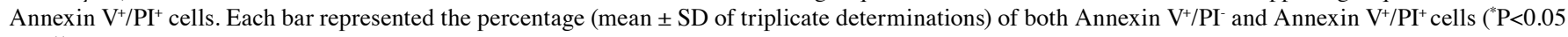
and ${ }^{* *} \mathrm{P}<0.01$ compared with the control). (B) LNCaP cells were treated with or without Sch $\mathrm{B}(0,12.5,25$ and $50 \mu \mathrm{M})$ for $48 \mathrm{~h}$. The cellular proteins were extracted to detect the levels of PARP, and caspase- 3 as well as $\beta$-actin (control) by western blotting. Sch B, Schisandrin B.

study evaluated whether Sch B can induce ROS in human prostate cancer $\mathrm{LNCaP}$ cells by treating cells with or without $\mathrm{N}$-acetyl-L-cysteine (NAC), an inhibitor of ROS, in presence or absence of Sch B $(12.5,25$ and $50 \mu \mathrm{M})$ and then analyzing the cells by flow cytometry. The results demonstrated that in the absence of NAC, Sch B increased the generation of ROS by $18.73 \pm 1.876 \%, 39.1 \pm 2.437 \%, 66.1 \pm 1.854$ and $73.36 \pm 1.629$ for $0,12.5,25$ and $50 \mu \mathrm{M}$, respectively, of Sch B, while the generation of ROS remained almost unchanged in presence of NAC for the same concentrations (Fig. 3A). This was due to the oxidative stress generated by Sch B in LNCaP cells resulting in an increased rate of ROS production.

The generation of ROS is mainly associated with the collapse of MMP in many cancer cells and induces cells apoptosis including in PC (20). To understand the role of Sch B in LNCaP cell apoptosis, the cells were stained with Rhodamine 123. Fig. 3B shows that, in the absence of NAC, the MMP expression was decreased $96.53 \pm 2.496,74.19 \pm 3.479$, 

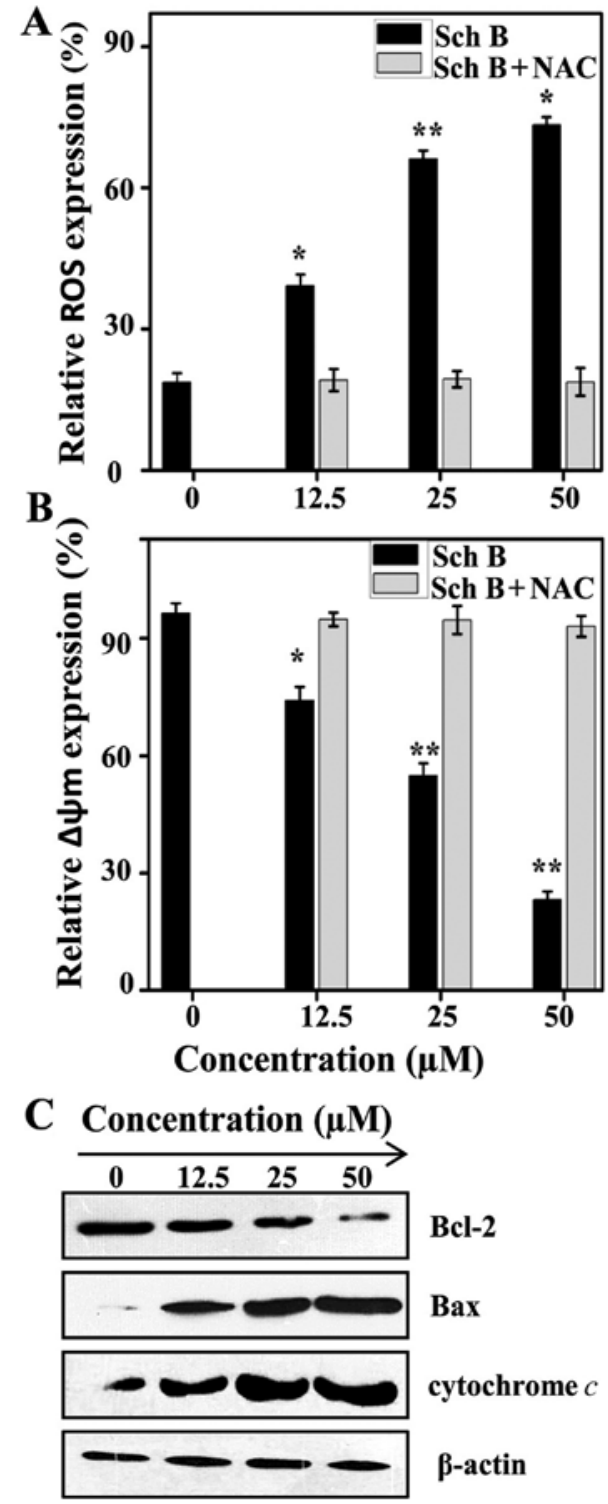

Figure 3. Sch B collapses mitochondrial membrane potential, while generating oxidative stress in $\mathrm{LNCaP}$ cells. (A) $\mathrm{LNCaP}$ cells were pre-incubated in the absence or presence of NAC $3 \mathrm{mM}$ for $30 \mathrm{~min}$, then treated with or without Sch B $(0,12.5,25$ and $50 \mu \mathrm{M})$ for $48 \mathrm{~h}$, and finally stained with DCFH-DA and analyzed by flow cytometry. ${ }^{*} \mathrm{P}<0.05$ and ${ }^{* *} \mathrm{P}<0.01$ compared with the control. (B) LNCaP cells were pre-incubated in the absence or presence of NAC $3 \mathrm{mM}$ for $30 \mathrm{~min}$, then treated with or without Sch B $(0,12.5,25$ and $50 \mu \mathrm{M}$ ) for $48 \mathrm{~h}$, and finally stained with Rhodamine 123 . The data shown are representative of three independent experiments with similar results. ${ }^{*} \mathrm{P}<0.05$ and ${ }^{* *} \mathrm{P}<0.01$ compared with the control. (C) LNCaP cells were treated with or without Sch B $(0,12.5,25$ and $50 \mu \mathrm{M})$ for $48 \mathrm{~h}$ and then cellular proteins were extracted to detect the levels of Bax, $\mathrm{Bcl}-2$, cytochrome $c$, as well as $\beta$-actin (control) protein. Sch B, Schisandrin B; NAC, N-acetyl-L-cysteine.

$54.82 \pm 3.2017$ and $23.21 \pm 2.1649 \%$ respectively for $0,12.5,25$, and $50 \mu \mathrm{M}$ of Sch $\mathrm{B}$, while the MMP expression remained unchanged for the same concentrations in presence of NAC. To further understand the mechanism by which Sch B decreased MMP, western blot analysis was conducted to confirm the level of cytochrome $c$, Bax, and Bcl-2 to obtain more insight into cell apoptosis. The results demonstrated that Sch B led to the release of cytochrome $c$ from the mitochondrial membrane. This consequently drove the activation of Bax and deactivated Bcl-2 (Fig. 3C). This release of cytochrome $c$ is the key factor in the formation of apoptosomes and is due to the role of the Bcl-2 protein family in the regulation of the apoptotic pathway of the mitochondrial membrane.

Sch B induces apoptosis via phosphorylated PI3K/Akt as well as $N F-\kappa B$ and overexpression of $p 38$. It has been demonstrated that $\mathrm{NF}-\kappa \mathrm{B}$ can regulate cell apoptosis and growth. Studies have analyzed the functional mechanism of PI3K/Akt, ERK and p38 by investigating $\mathrm{NF}-\kappa \mathrm{B}(21,22)$. The present study hypothesized that the pathway can be adjusted by Sch B. The functions of Sch B in Akt proteins, ERK and p38 in LNCaP and DU145 at different concentrations are discussed in the present study. Sch B induced overexpression of p38 while it inhibited phosphorylation of p-PI3K, p-Akt and p-ERK (Fig. 4A). To this end, the present study assumed that Sch B exercises its function through the PI3K/Akt, ERK and p38 pathways.

To further validate these findings, RT-qPCR was performed to evaluate the expression of Akt mRNA in LNCaP cells following exposure to Sch B. As shown in Fig. 4B, Sch B induced the inhibition of Akt expression in the LNCaP cell line.

Sch $B$ induces inhibition of AR, IL6- and STAT3 induced STAT3 transcription and STAT3 phosphorylation in LNCaP cells. It has been demonstrated that inhibition of the phosphorylation of STAT3 and JAK2 can lead to the apoptosis of cancer cells (23). The expression levels of JAK2 and STAT3 were assessed by western blot analysis. As demonstrated in Fig. 5A, Sch B induced inhibition of phosphorylation of JAK 2 and downstream STAT3; however, it was identified that total JAK2 and STAT-3 remain unchanged in LNCaP and DU145 cells. To further validate these findings, RT-qPCR was performed to evaluate the expression of STAT3 mRNA in LNCaP cells following exposure to Sch B $(12.5,25$ and $50 \mu \mathrm{M})$. As observed in Fig. 5B, Sch B induced inhibition of STAT3 mRNA levels. Next, transient luciferase and transfection tests in LNCaP cells were conducted and results confirmed our findings. As shown in Fig. 5C, Sch B influenced STAT3 transcription and this was increased in association with IL-6.

It has been reported that IL-6 can activate AR (24). Therefore, transient luciferase and transfection tests in LNCaP cells were performed to evaluate whether Sch B inhibited AR. As shown in Fig. 5D, treatment of LNCaP cells with IL-6 increased AR expression whereas in the presence of Sch B $(12.5,25$ and $50 \mu \mathrm{M})$ AR expression was inhibited.

Sch B induces LNCAP cell arrest at the $S$ phase. The regulation of the cell cycle is a key point of cell proliferation and survival, and a disturbance during cell cycle regulation results in cell death by apoptosis. Flow cytometry was performed to determine the stage at which Sch B induced cell cycle arrest. The results demonstrated an increased in $\mathrm{S}$ phase percentage of $5.1730 \pm 1.875,6.9490 \pm 1.683,51.033 \pm 2.0165$ and $54.966 \pm 2.3561 \%$, respectively for $0,12.5,25$ and $50 \mu \mathrm{M}$ of Sch B, while the percentage of G0/G1 53.751 \pm 2.54852 , $52.598 \pm 1.3794,35.102 \pm 2.13712$ and $27.31 \pm 2.141$ as well as the percentage of $\mathrm{G} 2 / \mathrm{M} 41.076 \pm 2.276,39.454 \pm 1.947,13.865 \pm 1.539$, $13.725 \pm 1.9853$ percentages decreased, respectively for the same concentrations. These results indicated that Sch B induced cell arrest of LNCaP cells at the S phase (Fig. 6A). 


\section{A}

\section{LNCaP}

DU145

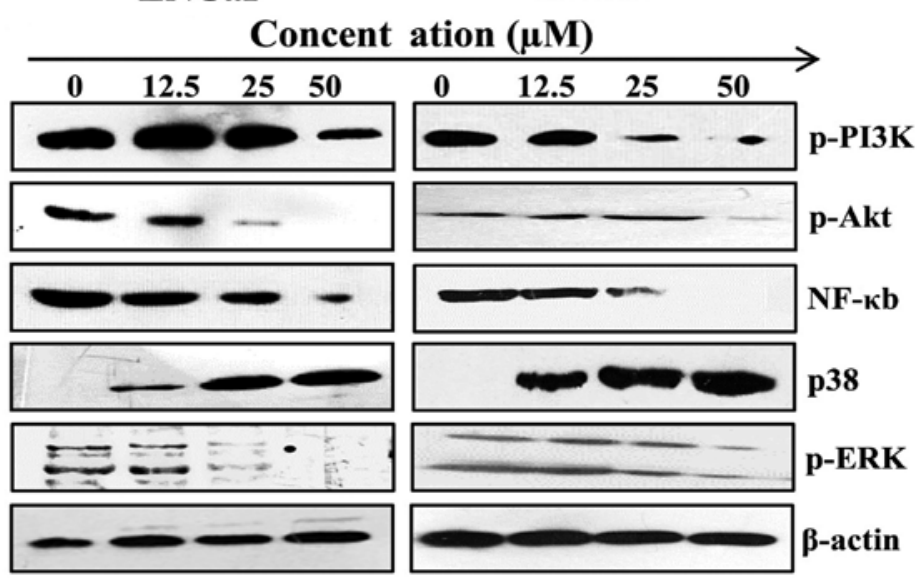

\section{B}

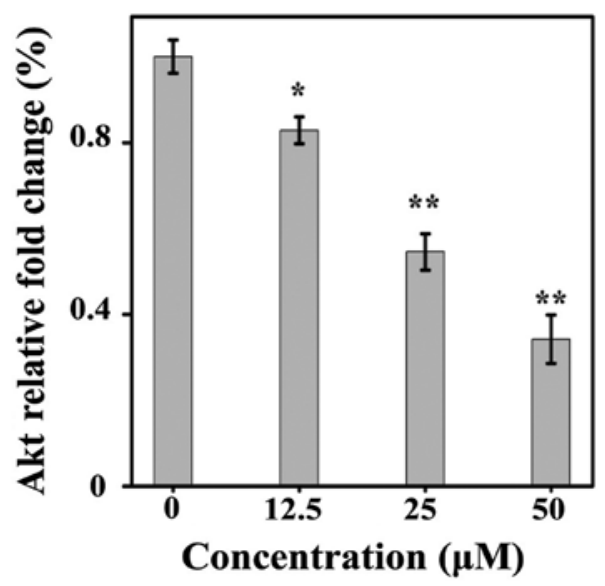

Figure 4. Sch B induces LNCaP and DU145 cell apoptosis by suppressing tumor necrosis factors and PI3K/Akt. (A) Cells were treated with or without Sch B (0, $12.5,25$ and $50 \mu \mathrm{M}$ ) for $48 \mathrm{~h}$. The cellular proteins were extracted to detect the levels of NF- $\mathrm{KB}, \mathrm{p}$-PI3K, p-Akt, p-ERK, p38 as well as $\beta$-actin (control) protein. (B) Real-time RT-PCR was used to quantify the Akt mRNA levels in LNCaP cells after treatment with Sch B $(0,12.5,25$ and $50 \mu \mathrm{M})$ for $24 \mathrm{~h}$. Fold decrease of gene expression was calculated by dividing the normalized gene expression activity by that of the untreated control. The data shown are representative of three independent experiments with similar results. ${ }^{*} \mathrm{P}<0.05$ and ${ }^{* *} \mathrm{P}<0.01$ compared with the control. Sch B, Schisandrin B.

To further elucidate the molecular mechanism underlying $\mathrm{S}$ phase arrest western blotting was performed to characterize the protein-regulated $\mathrm{S}$ phase. As shown in Fig. 6B, Sch B suppressed the expression of $\mathrm{pRb}$, cyclin E1, cyclin A1, cyclin D1, E2F1 and Mdm2 while increasing p53. These results confirmed $\mathrm{S}$-phase arrest.

\section{Discussion}

Previous studies have suggested a positive transactivation loop between STAT3 and Akt-NF- $\kappa$ B (25). Cells with anti-apoptotic ability usually have higher expression levels of STAT3 and Akt. Akt was inhibited through PI3K, which can reduce the regulation level of STAT3 (26). Similarly, STAT3 was inhibited if the regulation level of Akt was lowered by JAK2 (27). The PI3K/Akt pathway influences STAT tyrosine phosphorylation by Src tyrosine kinase, which is related to the cytokine receptors with PI3K by JAK2. JAK2 inhibited the transcription function of STAT, which was verified by the results of the present study. Sch B inhibited PI3K/Akt and the activity of JAK2 and STAT3. This negative effect eliminates the positive regulation effect of the feedback mechanism of maintaining equilibrium between STAT3 and Akt

The progression of cell apoptosis is impeded by $\mathrm{NF}-\kappa \mathrm{B}$, but STAT3 expression is accelerated by NF- $\kappa$ B. STAT3 induced by $\mathrm{NF}-\kappa \mathrm{B}$ and JAK 2 can prevent cell apoptosis and accelerate the expression of Akt, which has positive effects on apoptosis prevention. To sum up, JAK2 regulation can be reduced by the increase of Akt, which further decreases the expression of Akt and STAT3, and which leads to the negative feedback mechanism between STAT3 and Akt $(28,29)$. Akt can activate ERK in tumor cells (30).

These two feedback signals indicate that molecules serve an important role in cell proliferation, escape and apoptosis. Sometimes these two signal paths compensate for each other. Due to the limited efficacy of a single reagent, clinical trials are performed using the combined application of inhibitors that target pathways like ERK and PI3K. As a powerful inhibitor of ERK and Akt, Sch B can improve the antiproliferative effects of LNCaP cells compared with a single therapy. Therefore, Sch B can be considered as a potential natural antineoplastic alternative to ERK and Akt inhibitors (31). 
A

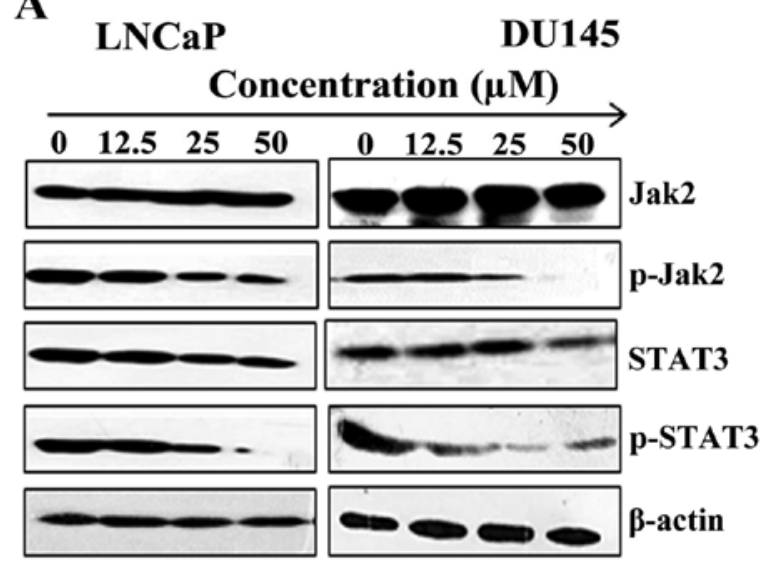

B

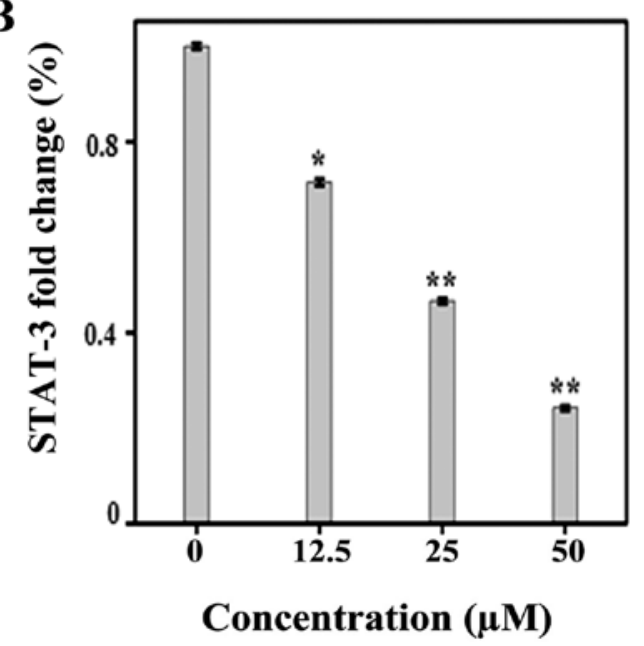

C

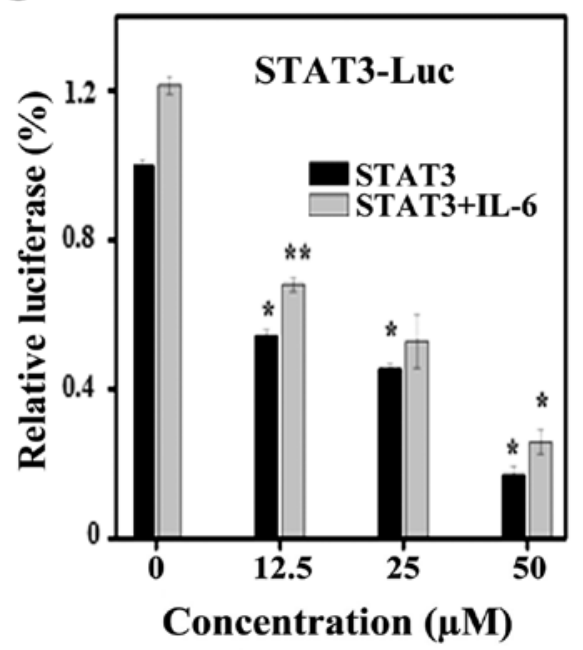

D

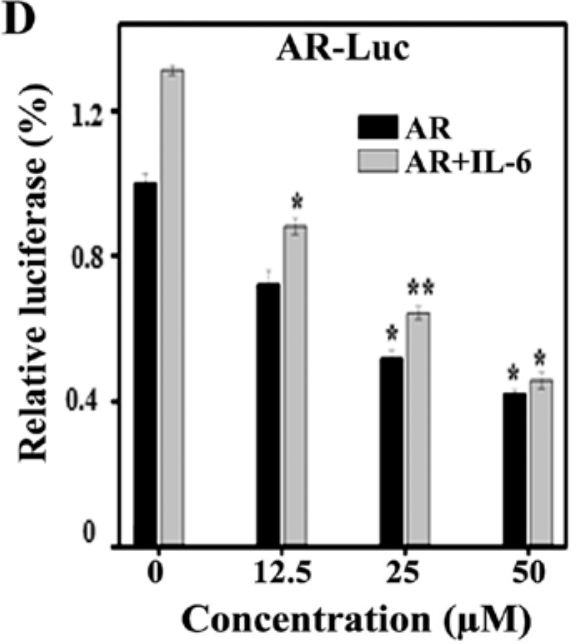

Figure 5. Sch B induces apoptosis in LNCaP cells through phosphorylation of JAK2 and STAT3 or AR independently of IL6 (A) LNCaP cells were treated with or without Sch B $(0,12.5,25$ and $50 \mu \mathrm{M})$ for $48 \mathrm{~h}$. The cellular proteins were extracted to detect the levels of JAK2, p-JAK2, STAT3, p-STAT3 as well as $\beta$-actin (control) by western blotting. (B) Real-time RT-PCR was used to quantify the STAT3 mRNA levels in LNCaP cells after treatment with Sch B $(0,12.5$, 25 and $50 \mu \mathrm{M}$ ) for $24 \mathrm{~h}$. Fold change of gene expression was calculated by dividing the normalized gene expression activity by that of the untreated control. The data shown are representative of three independent experiments with similar results. ${ }^{*} \mathrm{P}<0.05$; and ${ }^{* *} \mathrm{P}<0.01$ compared with the control $(\mathrm{C}) \mathrm{LNCaP}$ cells were transiently transfected with M67-Luciferase plasmid. After $16 \mathrm{~h}$ of transfections, the cells were treated with Sch B $(0,12.5,25$ and $50 \mu \mathrm{M})$ for $48 \mathrm{~h}$ and then harvested for luciferase assays. Cells were treated in the presence or absence of IL-6 $10 \mathrm{ng} / \mathrm{ml}$ for stimulation. ${ }^{*} \mathrm{P}<0.05$ and ${ }^{* * *} \mathrm{P}<0.01 \mathrm{compared}$ with the control. (D) LNCaP cells were transiently transfected with $0.5 \mathrm{mg}$ of AR-Luc plasmids. After $16 \mathrm{~h}$ of transfections, the cells were treated with Sch B $(0,12.5$, 25 and $50 \mu \mathrm{M}$ ) for $48 \mathrm{~h}$ and then harvested for luciferase assays. Cells were treated in the presence or absence of IL-6 $10 \mathrm{ng} / \mathrm{ml}$ for stimulation. "P<0.05 and ${ }^{* *} \mathrm{P}<0.01$ compared with the control. Sch B, Schisandrin B.

According to a previous study, Sch B maintains antioxidant properties (15). To verify whether the production of $\mathrm{H}_{2} \mathrm{O}_{2}$ can mediate cell apoptosis stimulated by Sch B in LNCaP cells, a flow cytometric analysis of ROS was performed. $\mathrm{H}_{2} \mathrm{O}_{2}$ was generated through Sch B, which was inhibited in the presence of NAC. Furthermore, the generation of ROS was associated with enhanced cell apoptosis. This demonstrated that Sch B has an antioxidant effect on prostate cancer.

The proliferation of cells is auto-regulated by the cell cycle, which is regulated through a myriad of complex CDK and cyclin-CDK proteins. The cell channel in G0/G1 to S-phase is synchronized through the composite cyclinE-CDK2 (32). The introduction of $\mathrm{E} 2 \mathrm{~F} 1$ is prompted, via phosphorylated $\mathrm{pRb}$, to enter G2/M transition (33). LNCaP cells were treated with Sch B, which reduced the levels of both cyclin E and CDK2. The expression of $\mathrm{p} 21$ was enhanced by phosphorylated $\mathrm{pRb}$.
Therefore, the S phase arrest in $\mathrm{LNCaP}$ cells may be caused by the decrease of the complex CyclinE/CDK2 and enhanced regulation of $\mathrm{p} 21$.

In summary, the present study predominantly explained the mitochondrial anti-proliferation role and pro-apoptosis role of Sch B in PC (LNCaP and DU145) cells. Sch B was identified to inhibit phosphorylation of JAK2 and itsdownstream STAT3. The inhibition of the phosphorylation of JAK2 by Sch B resulted in the inhibition of PI3K/Akt. Furthermore, JAK2 inhibition by Sch B led to the inhibition of Bcl-2, promoted mitochondrial membrane potential expression collapse with induced oxidative stress in LNCaP cells therefore leading cells to apoptosis. In addition, we found that Sch B induced $\mathrm{LNCaP}$ cell inhibition of STAT3 and AR, which was dependent of IL-6. Finally, Sch B-induced LNCaP toxicity was associated with $\mathrm{S}$-phase cell cycle arrest. 
$\mathbf{A}$

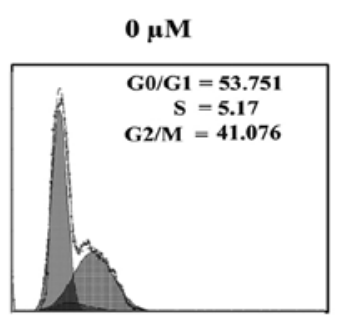

$25 \mu \mathrm{M}$
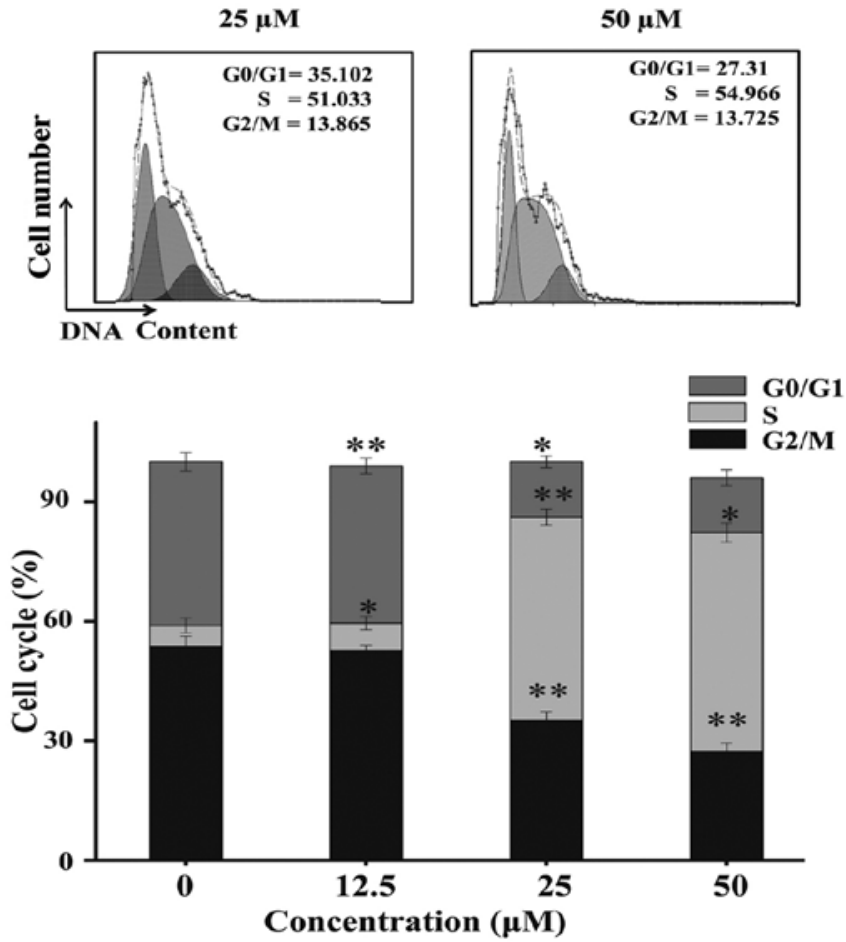

B

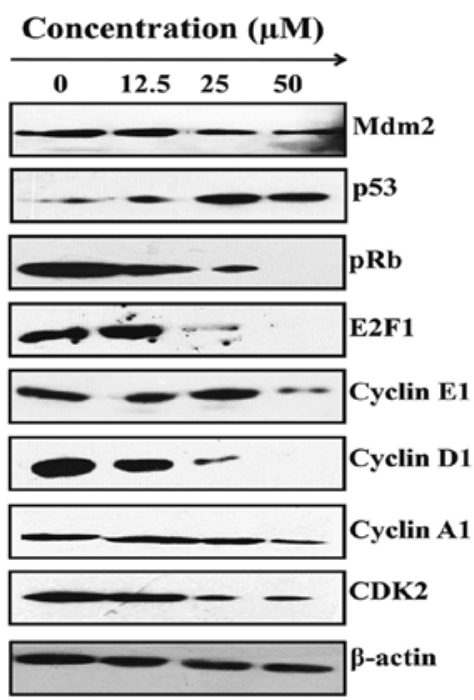

Figure 6. Sch B induces LNCaP cell cycle arrest at the S phase. (A) LNCaP cells were treated with or without Sch B $(0,12.5,25$ and $50 \mu \mathrm{M})$ for $48 \mathrm{~h}$, and then they were stained with PI for flow cytometric analysis. Histograms show the number of cells/channel (y-axis) vs. DNA content (x-axis). The values indicate the percentage of cells in the indicated phases of the cell cycle. The data shown are representative of three independent experiments with the similar results. "P<0.05; and ${ }^{* *} \mathrm{P}<0.01$ compared with the control. (B) LNCaP cells were treated with or without Sch B $(0,12.5,25$ and $50 \mu \mathrm{M})$ for $48 \mathrm{~h}$. The cellular proteins were extracted to detect the levels of p53, pRb, cyclin A1, cyclin D1, cyclin E1, CDK2, E2F1, Mdm2 as well as $\beta$-actin (control) by western blotting. Sch B, Schisandrin B.

\section{Acknowledgements}

The authors gratefully acknowledge the supports from Liaoning Provincial Post Graduate Launching foundation 201601300.

\section{Funding}

The present study was supported by the Liaoning Provincial Post Graduate Launching foundation 201601300.

\section{Availability of data and materials}

The datasets used during the present study are available from the corresponding author upon reasonable request.

\section{Authors' contributions}

MIN and NJ conceived and designed the study. MIN, TH, SA and YT performed the experiments, collected and analyzed the data. MIN, SA, YT and NJ wrote, reviewed and edited the manuscript. All authors contributed equally in this study.
All authors read and approved the manuscript and agree to be accountable for all aspects of the research in ensuring that the accuracy or integrity of any part of the work are appropriately investigated and resolved.

\section{Ethics approval and consent to participate}

Not applicable.

\section{Patient consent for publication}

Not applicable.

\section{Competing interests}

The authors declare that they have no competing interests.

\section{References}

1. Ho Y and Dehm SM: Androgen receptor rearrangement and splicing variants in resistance to endocrine therapies in prostate cancer. Endocrinology 158: 1533-1542, 2017. 
2. Pedraza-Arevalo S, Hormaechea-Agulla D, Gomez-Gomez E, Requena MJ, Selth LA, Gahete MD, Castaño JP and Luque RM: Somatostatin receptor subtype 1 as a potential diagnostic marker and therapeutic target in prostate cancer. Prostate 77: 1499-1511, 2017.

3. Culig Z: Androgen receptor coactivators in regulation of growth and differentiation in prostate cancer. J Cell Physiol 231: 270-274, 2016.

4. Luo $\mathrm{C}$ and Zhang $\mathrm{H}$ : The role of proinflammatory pathways in the pathogenesis of colitis-associated colorectal cancer. Mediators Inflamm 2017: 5126048, 2017.

5. Debes JD, Schmidt LJ, Huang H and Tindall DJ: p300 mediates androgen-independent transactivation of the androgen receptor by interleukin 6. Cancer Res 62: 5632-5636, 2002.

6. Han IH, Kim JH, Kim SS, Ahn MH and Ryu JS: Signalling pathways associated with IL-6 production and epithelial-mesenchymal transition induction in prostate epithelial cells stimulated with Trichomonas vaginalis. Parasite Immunol 38: 678-687, 2016

7. Xie S, Lin HK, Ni J, Yang L, Wang L, di Sant'Agnese PA and Chang C: Regulation of interleukin-6-mediated PI3K activation and neuroendocrine differentiation by androgen signaling in prostate cancer LNCaP cells. Prostate 60: 61-67, 2004.

8. Yang L, Wang L, Lin HK, Kan PY, Xie S, Tsai MY, Wang PH, Chen YT and Chang C: Interleukin-6 differentially regulates androgen receptor transactivation via PI3K-Akt, STAT3, and MAPK, three distinct signal pathways in prostate cancer cells. Biochem Biophys Res Commun 305: 462-469, 2003.

9. Liu N, Zheng JX, Zhuang YS, Zhou ZK, Zhao JH and Yang L: Anti-inflammatory effects of Schisandrin B on LPS-stimulated BV2 microglia via activating PPAR- $\gamma$. Inflammation 40: 1006-1011, 2017.

10. Checker R, Patwardhan RS, Sharma D, Menon J, Thoh M, Bhilwade HN, Konishi T and Sandur SK: Schisandrin B exhibits anti-inflammatory activity through modulation of the redox-sensitive transcription factors $\mathrm{Nrf} 2$ and $\mathrm{NF}-\kappa \mathrm{B}$. Free Radic Biol Med 53: 1421-1430, 2012.

11. Yang X, Wang S, Mu Y and Zheng Y: Schisandrin B inhibits cell proliferation and induces apoptosis in human cholangiocarcinoma cells. Oncol Rep 36: 1799-1806, 2016.

12. Liu XN, Zhang CY, Jin XD, Li YZ, Zheng XZ and Li L: Inhibitory effect of Schisandrin B on gastric cancer cells in vitro. World J Gastroenterol 13: 6506-6511, 2007.

13. Jiang Y, Zhang Q, Bao J, Du C, Wang J, Tong Q and Liu C: Schisandrin B suppresses glioma cell metastasis mediated by inhibition of mTOR/MMP-9 signal pathway. Biomed Pharmacother 74: 77-82, 2015.

14. Xin DQ, Hu ZM, Huo HJ, Yang XJ, Han D, Xing WH, Zhao Y and Qiu QH: Schisandrin B attenuates the inflammatory response, oxidative stress and apoptosis induced by traumatic spinal cord injury via inhibition of p53 signaling in adult rats. Mol Med Rep 16: 533-538, 2017.

15. Inoue H, Waiwut P, Saiki I, Shimada Y and Sakurai H: Gomisin $\mathrm{N}$ enhances TRAIL-induced apoptosis via reactive oxygen species-mediated up-regulation of death receptors 4 and 5. Int J Oncol 40: 1058-1065, 2012.

16. Nasser MI, Masood M, Wei W, Li X, Zhou Y, Liu B, Li J and Li X: Cordycepin induces apoptosis in SGC7901 cells through mitochondrial extrinsic phosphorylation of PI3K/Akt by generating ROS. Int J Oncol 50: 911-919, 2017.

17. Livak KJ and Schmittgen TD: Analysis of relative gene expression data using real-time quantitative PCR and the $2^{-\Delta \Delta C_{T}}$ method. Methods 25: 402-408, 2001.

18. Mao J, Hu X, Pang P, Zhou B, Li D and Shan H: miR-30e acts as a tumor suppressor in hepatocellular carcinoma partly via JAK1/STAT3 pathway. Oncol Rep 38: 393-401, 2017.

19. Kim KY, Park KI, Kim SH, Yu SN, Park SG, Kim YW, Seo YK, Ma JY and Ahn SC: Inhibition of autophagy promotes salinomycin-induced apoptosis via reactive oxygen species-mediated $\mathrm{PI} 3 \mathrm{~K} / \mathrm{AKT} / \mathrm{mTOR}$ and ERK/p38 MAPK-dependent signaling in human prostate cancer cells. Int J Mol Sci 18: E1088, 2017.
20. Changou CA, Chen YR, Xing L, Yen Y, Chuang FY, Cheng RH, Bold RJ, Ann DK and Kung HJ: Arginine starvation-associated atypical cellular death involves mitochondrial dysfunction, nuclear DNA leakage, and chromatin autophagy. Proc Natl Acad Sci USA 111: 14147-14152, 2014.

21. Dilly AK, Ekambaram P, Guo Y, Cai Y, Tucker SC, Fridman R, Kandouz $M$ and Honn KV: Platelet-type 12-lipoxygenase induces MMP9 expression and cellular invasion via activation of PI3K/Akt/NF-kB. Int J Cancer 133: 1784-1791, 2013.

22. He Y, Huang H, Farischon C, Li D, Du Z, Zhang K, Zheng X and Goodin S: Combined effects of atorvastatin and aspirin on growth and apoptosis in human prostate cancer cells. Oncol Rep 37: 953-960, 2017.

23. Abedinpour P, Baron VT, Chrastina A, Rondeau G, Pelayo J, Welsh J and Borgström P: Plumbagin improves the efficacy of androgen deprivation therapy in prostate cancer: A pre-clinical study. Prostate 77: 1550-1562, 2017.

24. Culig Z and Puhr M: Interleukin-6: A multifunctional targetable cytokine in human prostate cancer. Mol Cell Endocrinol 360: 52-58, 2012.

25. Huang WL, Yeh HH, Lin CC, Lai WW, Chang JY, Chang WT and Su WC: Signal transducer and activator of transcription 3 activation up-regulates interleukin-6 autocrine production: A biochemical and genetic study of established cancer cell lines and clinical isolated human cancer cells. Mol Cancer 9: 309 , 2010.

26. Li Y, Zhu W, Tao J, Xin P, Liu M, Li J and Wei M: Fasudil protects the heart against ischemia-reperfusion injury by attenuating endoplasmic reticulum stress and modulating SERCA activity: The differential role for PI3K/Akt and JAK2/STAT3 signaling pathways. PLoS One 7: e48115, 2012.

27. Shanmugam MK, Rajendran P, Li F, Nema T, Vali S, Abbasi T, Kapoor S, Sharma A, Kumar AP, Ho PC, et al: Ursolic acid inhibits multiple cell survival pathways leading to suppression of growth of prostate cancer xenograft in nude mice. J Mol Med 89: 713-727, 2011.

28. Ma M, Ma Y, Zhang GJ, Liao R, Jiang XF, Yan XX, Bie FJ, Li XB and Lv YH: Eugenol alleviated breast precancerous lesions through HER2/PI3K-AKT pathway-induced cell apoptosis and S-phase arrest. Oncotarget 8: 56296-56310, 2017.

29. Cho SH, Park MH, Lee HP, Back MK, Sung HC, Chang HW, Kim JH, Jeong HS, Han SB and Hong JT: $(E)-2,4-B i s(p-h y d r$ oxyphenyl)-2-butenal enhanced TRAIL-induced apoptosis in ovarian cancer cells through downregulation of NF- $\mathrm{KB} / \mathrm{STAT} 3$ pathway. Arch Pharm Res 37: 652-661, 2014.

30. Selvaraj N, Budka JA, Ferris MW, Jerde TJ and Hollenhorst PC: Prostate cancer ETS rearrangements switch a cell migration gene expression program from RAS/ERK to PI3K/AKT regulation. Mol Cancer 13: 61, 2014.

31. Chae JK, Subedi L, Jeong M, Park YU, Kim CY, Kim H and Kim SY: Gomisin N inhibits melanogenesis through regulating the PI3K/Akt and MAPK/ERK signaling pathways in melanocytes. Int J Mol Sci 18: E471, 2017.

32. Ye D, Luo H, Lai Z, Zou L, Zhu L, Mao J, Jacob T, Ye W, Wang L and Chen L: ClC-3 chloride channel proteins regulate the cell cycle by up-regulating cyclin D1-CDK4/6 through suppressing p21/p27 expression in nasopharyngeal carcinoma Cells. Sci Rep 6: 30276, 2016.

33. Hamid SM, Cicek S, Karamil S, Ozturk MB, Debelec-Butuner B, Erbaykent-Tepedelen B, Varisli L, Gonen-Korkmaz C, Yorukoglu K and Korkmaz KS: HOXB13 contributes to G1/S and G2/M checkpoint controls in prostate. Mol Cell Endocrinol 383: 38-47, 2014. 